\title{
Effect of Harvest Age on Growth, Yield and Quality of Two Root Chicory Varieties (Cichorium intybus L.) under Egyptian Conditions Aly, E. F. A. ${ }^{1}$ and Soha R. A. Khalii ${ }^{2}$ \\ ${ }^{1}$ Var. Mainten. Res. Dept. - Sugar Crops Res. Inst., Agric. Res. Center, Giza, Egypt, (ARC). \\ ${ }^{2}$ Sugar Technol. Dept. - Sugar Crops Res. Inst., Agric. Res. Center, Giza, Egypt, (ARC).
}

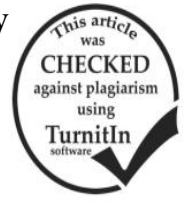

\section{ABSTRACT}

Chicory (Cichorium intybus L.) related to the family Asteraceae is a winter crop and stores inulin in the taproots. Chicory is considerable a cash crop, whereas inulin is a polyfructans, which is widely used as prebiotic, sugar replacer, fat replacer, starting material for fructose syrup and oligofructose in several industrial applications. Thus, two field experiments were carried out in 2014/2015 and 2015/2016 seasons at El-Giza Agricultural Station Agricultural Research Center in Egypt (latitude of 30 ${ }^{\circ}$ $03 \mathrm{~N}$ and longitude of $31^{\circ} 13 \mathrm{E}$ ) in a clay soil to evaluate the performance of two French chicory varieties namely Nues and Eurobees for its growth, yield and quality under three harvest ages 125,145 and 165 days after sowing date in (October $15^{\text {th }}$ in the two growing seasons). The experimental design was split plots with four replications. The results indicated that the two chicory varieties differed considerably concerning their potential of growth, yield and quality characteristics. Eurobees variety surpassed Nues in root formation, root fresh and dry yields/fed, inulin\% and inulin yield/fed.Delaying harvest ages from 125 to 145 and up to 165 day after sowing caused significant increases in fresh and dry root yields/fed, inulin \% and inulin yield/fed in both seasons. The interaction between Chicory varieties and harvest ages indicated that Eurobees achieved the highest significant values of root fresh, root dry and inulin yields/fed with delaying harvest age to 165 days after sowing as compared to Nues variety harvested at 125 days. Both Eurobees and Nues varieties which harvested at 165 days from sowing attained the highest significant variance of inulin $\%$ as compared to them at $12^{\circ}$ and/or 145 days after sowing.As for enzymetic analyses of inulin extracted from sample of root dry at the three harvesting ages under this work indicated that Eurobees has the longest inulin chain length, while Nues was the shortest inulin chain length. Thus, the variation in quality traits of the two chicory varieties allows a wide spectrum of utilization in food and pharmaceutical industries in Egypt. Under conditions of this present work, it could be recommended that both root chicory varieties sowing in October and must be harvesting at 165 days after sowing to get the highest yields of fresh and dry roots as well as inulin\% and inulin yield/fed, also for highest total fructose, reducing sugar percentages.

Keywords: Harvest age, root chicory varieties, root and inulin yield, inulin chain length

\section{INTRODUCTION}

The words chicory, succory, Cichorium intybus L are all derived from Greek or Latin names for the herb. The crop native to Europe, and is traditionally grown for use as a coffee substitute, chicory drink, or for use in the sugar industry. The current production area for "sugar chicory" is more than 15,000 ha and is concentrated in Belgium, France and the Netherlands. Recently, new regions such as Poland, Puerto Rico, and Serbia have been trying to introduce industrial chicory into their cropping systems (FAO, 2013). Introduction of new crops into agricultural production systems is desirable to overcome problems associated with narrow crop rotation. Chicory is considered one of the most important sources of fractan type inulin since it has a high root yield potential and high inulin content (Schittenhelm, 1999). Chicory is winter crop which is a cold-requiring and long-day plant. Chicory is an annual and/or biannual with self-incompatibility characteristics (Zagal et al., 2001). Schittenhelm (2001) reported that root chicory is a potential alternative sugar crop which accumulates a high amount of linear fructose polymers (fructan) in its roots. Wilson et al. (2004) reported that glucose, fructose, sucrose, and fructans were as a percentage of total sugar content. Andrea et al. (2005) reported that fructans were further grouped into three categories: DP 3 to 10 fructans (short chain-length fructans), DP 11 to 20 fructans (medium chain-length fructans) and DP $>20$ fructans (long chain-length fructans). Chicory plants related to the family Asteraceae manufactures linear inulin (fructan) consisting of one terminal glucose residue and a variable number of fructose residues exclusively linked by $\beta-(2 \rightarrow 1)$ bonds (Van Arkel et al., 2012).

The fructans are group of storage polysaccharides which the human body is unable to metabolize. Therefore, the fructans are considered dietary functional food ingredients (Ritsema and Smeekens, 2003). Chicory is an attractive as a cash crop since it can reach more than 50-62 tons $\mathrm{ha}^{-1}$ under favourable conditions. Meanwhile, inulin content can reach on average 15-20\% of root fresh weight and a yield of 8 tons ha $^{-1}$ of inulin is achievable (Papetti et al., 2013). Inulin is a poly fructans which is widely used as prebiotic, as a (low calorie) sweetener, fat replacer texture modifier and several industrial and pharmaceuticals (GonzálezHerrera et al., 2015).

Construction of chicory yield and technological quality is complex process, which depends on many factors such as varieties. Both developmental and biomass transformation processes are reflected into growth of chicory root biomass (Dersch et al., 1993) .Dried chicory root extract contains by weight approximately $98 \%$ inulin and $2 \%$ other compounds, while fresh chicory root may contain between 13 and $23 \%$ inulin, $14 \%$ sucrose, $5 \%$ cellulose, $6 \%$ protein, $4 \%$ ash, $89.4 \%$ total carbohydrate and $3 \%$ other components by total weight (Meehye and Shin, 1996).

In addition, an important factor to boost yield production is the selection of suitable varieties for specific environmental conditions and optimalization of agro-technical activities (Černý et al., 2008).

Baert (1997) concluded that the total amount of accumulated inulin in root is a role of variety. Kristine Koch et al. (1999) studied the effect of five harvest ages $(121,145,158,170$ and 183 days after sowing 
date) on quality of inulin chicory root for six chicory cultivars, namely Orchies (French), Bergues (French), Tilda (Belgian), SZ 05-004.94 (Austrian), Cassel (French) and Rubis (French). They found that varieties varied with harvest age and the highest degree of polymerization (DP) for all cultivars was detected for harvests in 158 and 170 days after sowing. Černý et al. (2008) noted that suitable variety is necessary support on the basis of ability to adapt to physical environment. Kovár and Černý (2012) evaluated two chicory varieties ('Fredonia Nova' and 'Oesia' a 'Maurane') to growth, yield potentials, inulin content. Fredonia Nova' gave higher roots value $2.08 \mathrm{~kg} \mathrm{~m}^{-2}$ and $205.9 \mathrm{mg} \mathrm{g}^{-1}$ dry weight more than in the variety 'Oesia' a 'Maurane'. Fredonia Nova variety gave the highest root yield by amount $25.73 \mathrm{t} \mathrm{ha}^{-1}$ and $25.02 \mathrm{t} \mathrm{ha}^{-1}$, while inulin content in fresh root were $20.85 \%$ and $21.54 \%$ with varieties 'Oesia' a, Maurane and Fredonia Nova, respectively in the first and second seasons. Sayed, Hala and Soha, Khalil (2017) reported that the quantity and quaintly of chicory root depends on variety.

Although different factors such as harvest date, temperature can affect inulin yield (Baert and Van Bockstaele, 1993). The content of free fructose and sucrose increased while the content of free glucose decreased with delaying harvest time Varallo et al. (1993). However, Ernst et al. (1995) mentioned that fructan yield and their degree of polymerization DP, influenced by climate and time harvest. Amaducci and Pritoni (1997) showed that retarding harvest time much affects the content and concentration of inulin content. Delaying harvesting time increased the root yield, total sugar content, total reducing sugar and inulin chain length. Moreover, the optimum date of harvesting roots is in non-physiological state and is given by the total content of sugars, as well as their ratio. On the other hand, Shoorideh et al. (2016) mentioned that root yield and inulin percentage are two major components to increase inulin yield.

The aim of this work was to evaluate the performance of two root chicory varieties for their growth, yield and quality characters at the three harvest ages under the Egyptian conditions.

\section{MATERIALS AND METHODS}

Two field experiments were carried out in 2014/2015 and 2015/2016 seasons at El-Giza Agriculture Station, Agricultural Research Center in Egypt, (latitude of $30^{\circ} 03 \mathrm{~N}$ and longitude of $31^{\circ} 13 \mathrm{E}$ ) in a clay soil to evaluate the performance of two French root chicory varieties namely Nues and Eurobees (Chiorium intybus L.) for its growth, yield and quality under three harvest ages $(125,145$ and 165 days after sowing on October $15^{\text {th }}$ ) in the two growing seasons. The size of each plot was $15 \mathrm{~m}^{2}$ consisted of 5 ridges with $5 \mathrm{~m}$ length and $0.6 \mathrm{~m}$ width. The experimental design was split plots with four replications. The two varieties were sown randomly in the main plots, while the three harvest ages were in the sub plots. Chicory seeds sown mixed with amount of sand; seeds depth was $2-3 \mathrm{~cm}$. Plant spacing within ridges was $15-17 \mathrm{~cm}$, plant population was about 9-11 plants per $\mathrm{m}^{2}$ after manual thinning (20 days from sowing and after full emergence). In both seasons, the trials were carried out on a well prearranged clay soil, with relatively apparent water. The agricultural practices were done. Mediate furrow irrigation was made to make easy the emergence of the crop sowing. Weeds were controlled manually from emergence until crop closure.

Phosphorus fertilizer was applied in the form of calcium super phosphate $\left(15 \% \mathrm{P}_{2} \mathrm{O}_{5}\right)$ at the rate of 100 $\mathrm{kg} / \mathrm{fed}$ and potassium fertilizer was applied at the rate of 24 $\mathrm{kg} / \mathrm{fed}$ in the form of potassium sulfate $\left(48 \% \mathrm{~K}_{2} \mathrm{O}\right)$ at seed bed preparation. Nitrogen fertilizer was applied as Urea $(46.5 \% \mathrm{~N})$ at the rate of $50 \mathrm{~kg} / \mathrm{fed}$ applied in two equal doses after thinning and the other two weeks later. Soil samples $(0-30 \mathrm{~cm}$ depth) were collected from the experimental site to determine its physical and prepared for mechanical and chemical analyses, according to Piper (1955) as shown in Table 1.

The monthly temperature degrees $\left({ }^{0} \mathrm{c}\right)$ of the two seasons were shown in Table 2.

At each harvest age, randomly sample of 10 plants were obtained from each plots and prepared for laboratory analyses to determine the following traits: 1 . Root length (cm), 2. Root diameter $(\mathrm{cm}), 3$. Root fresh weight $(\mathrm{g}), 4$. Foliage fresh weight $(\mathrm{g}), 5$. Root dry matter $\%$; $100 \mathrm{~g}$ homogeneous slices of fresh chicory roots were dried at $75^{\circ} \mathrm{c}$ for $48 \mathrm{~h}$.

\section{Root dry weight (g/plant) using the following formula:}

Root dry weight $(\mathrm{g} / \mathrm{plant})=$ root fresh weight $(\mathrm{g})$ $\mathrm{x}$ root dry matter $\%$

The three inside ridges at each harvest age $\left(9 \mathrm{~m}^{2}\right)$ were manually harvested, topped, washed, weighed (roots and tops) in all plots to calculate the following traits:

7. Root fresh yield (t/fed). (feddan $=2.4 \mathrm{ha}), 8$. Top fresh yield $(t /$ fed),

\section{Root dry yield (t/fed) using the following formula:} Root dry yield $(\mathrm{t} / \mathrm{fed})=$ Root fresh yield $(\mathrm{t} / \mathrm{fed}) \mathrm{x}$ Root dry matter\%.

Preparation of chicory:

The plant of chicory root was washed with tap water to remove remaining soil and other impurities and then cut them into small pieces and dried at $40^{\circ} \mathrm{C}$ for 10 hr. in an electric oven (Gasellsaft for Laboratory, D3006, German), then ground using an electrical mill to pass through 100 mesh sieves and stored in polyethylene bags in refrigerator at $4{ }^{\circ} \mathrm{C}$ until used.

\section{Chemical analyses on dry weight basis:}

Inulin was determined using HPLC the chromatographic equipment consists of a Model LC20AT pump system (Shimadzu, Japan), a 20-1L sample loop, and a LC solution system, which acquires data from the refractive index detector (RID 10A, Shimadzu, Tokyo, Japan). The analytical column put to use in this case is Shim-pack SCR 101C from Shimadzu (Tokyo, Japan). Inulin was determined according to the methods described by Wang et al. (2010) and inulin yield ( $\mathrm{t} / \mathrm{fed})$ was calculated as root yield ( $\mathrm{t} / \mathrm{fed}) \mathrm{x}$ inulin $\%$ 
Extraction of inulin from root chicory:

The extraction process was made by adding hot water to the roots powder, in a 1:2 proportion (roots: water) at the average temperature of $80^{\circ} \pm 2 \mathrm{C}$ for $1 \mathrm{hr}$ with constant agitation. The liquid inulin extracts obtained was filtered (Leite et al. 2004). The extracted filtrate was then concentrated according to (Amin, 1997). The concentrated extract was dried firstly by freezing and water portion separation, and then the concentrated portion was oven dried under vacuum at $40^{\circ} \mathrm{C}$ to reach a complete dryness

Table 1. Particle size distribution and some chemical properties of the soil of the experimental site in 2014/2015 and 2015/2016 seasons

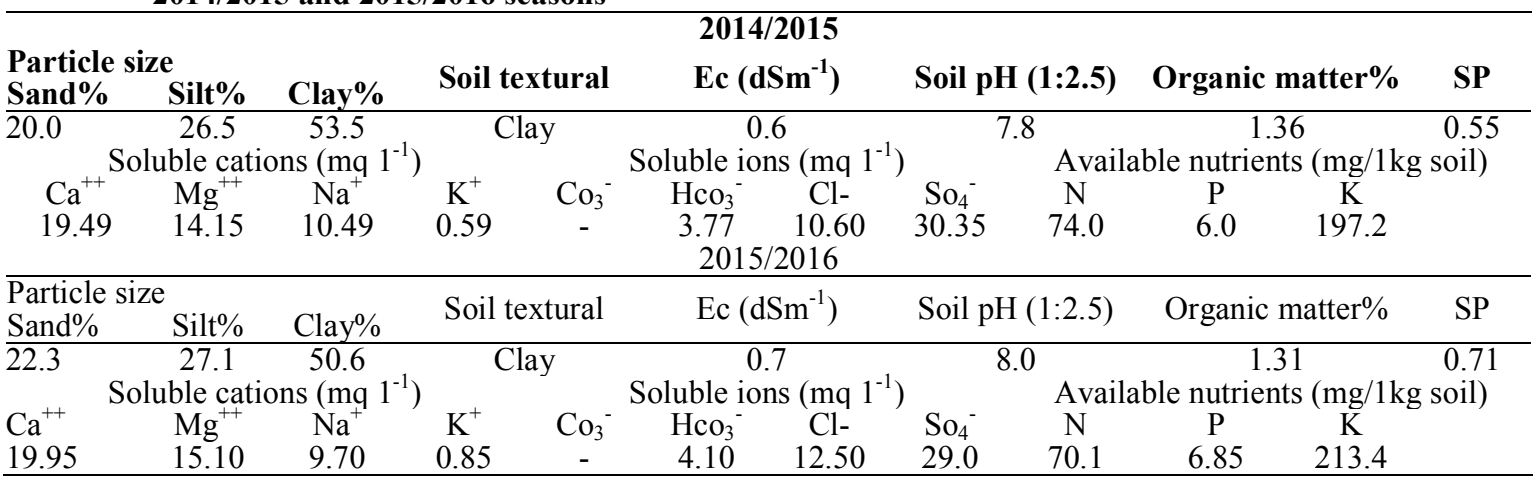

Table 2. The temperature degrees and relative humidity of the two seasons at El-Giza.

\begin{tabular}{lcccccccc}
\hline Month & \multicolumn{3}{c}{$\begin{array}{c}\mathbf{2 0 1 4} / \mathbf{2 0 1 5} \text { season } \\
\text { Mx. temp. }\end{array}$} & $\begin{array}{c}\text { Min. temp. Av. Temp. } \\
\text { Relative } \\
\text { humidity\% }\end{array}$ & \multicolumn{3}{c}{$\begin{array}{c}\text { 2015/2016 season } \\
\text { Mx. Temp. }\end{array}$} & $\begin{array}{c}\text { Min. temp. Av. Temp. } \\
\text { Relative } \\
\text { humidity\% }\end{array}$ \\
\hline October & 30.9 & 18.5 & 25.0 & 63.7 & 32.7 & 20.7 & 28.3 & 57.0 \\
November & 26.1 & 13.9 & 21.6 & 59.3 & 26.9 & 15.7 & 22.9 & 46.0 \\
December & 24.6 & 11.4 & 19.6 & 56.0 & 21.6 & 9.9 & 17.6 & 64.7 \\
January & 19.9 & 7.1 & 15.8 & 54.0 & 23.0 & 11.1 & 15.5 & 60.3 \\
February & 21.4 & 8.2 & 16.9 & 51.0 & 22.9 & 10.3 & 16.9 & 54.0 \\
Marsh & 25.4 & 12.1 & 21.0 & 52.0 & 25.5 & 12.6 & 19.1 & 43.3 \\
April & 28.8 & 12.0 & 23.6 & 43.0 & 30.3 & 15.2 & 23.4 & 38.3
\end{tabular}

Source: Agro-meteorological station, Agric. Res. Center, Giza, Egypt,

Determination sugar profile and degree of polymerization (DP):

At each harvest age, randomly sample of 10 plants were obtained and prepared for laboratory analyses to determine the following traits by enzymatic hydrolysis, this process is the hydrolysis of inulin by inulinases to determine chain length of extracted inulin from dried roots of the two tested varieties according to the method described by (Petkova et al. 2015), then the samples were measured by Spectrophotometer measuring the absorption at wave length $410 \mathrm{~nm}$ for reducing groups and $480 \mathrm{~nm}$ for total fructose content and calculation by the following formula:

Total glucose content $=$ reducing groups - total fructose content

Degree of polymerisation (DP) $=$ (fructose content/glucose content) +1

At 165 days from sowing, Moisture, protein, fat, crude fiber and ash content of two chicory root variety samples were determined according to the methods described in AOAC (2010). Total carbohydrates content was calculated by difference.

At 165 days from sowing, Minerals content was estimated by Atomic Absorption pectrophotometer (model 3300, Perkin- Elimer, Beaconsfield, UK) and digestion according to the procedure outlined by AOAC (2010).

\section{Statistically analysis}

All measured and derived data were analyzed separately for each season by analysis of variance (ANOVA) as shown by Snedecor and Cochran (1980) using the technique of (MSTAT-c) computer software package. Least significant differences (LSD) method was used to test the differences between treatment means at $5 \%$ level of probability as described by Duncun (1955).

\section{RESULTS AND DISCUSSION}

Data in Table 3 show that the difference between the two chicory varieties in root diameter, root fresh weight and foliage fresh weight traits were significant in both seasons except root length. Eurobees variety recorded an increase in root diameter amounted to 1.0 and $1.3 \mathrm{~cm}$, corresponding to 33 and $29 \mathrm{~g}$ in root fresh weight $\mathrm{g} / \mathrm{plant}$, as well as 14 and $13 \mathrm{~g}$ in foliage weight $\mathrm{g} /$ plant in the $1^{\text {st }}$ and $2^{\text {nd }}$ season, respectively, as compared to Nues variety. The variation between the two tested chicory varieties in these traits might be due to their gene make-up.

These results are in line with those mentioned by Papetti et al. (2013) they obtained that significant differences among the tested root chicory varieties in root parameters. 
Regarding harvest age, data in the same table indicate that decreasing harvesting age from 125 to145 and up to 165 days after sowing significantly and gradually increased all mentioned characters except foliage fresh weight $\mathrm{g} /$ plant which showed an opposite trend, in both seasons. These results are in harmony with those obtained by Dersch et al. (1993).

Table 3. Root length, root diameter $(\mathrm{cm})$, root and foliage fresh weight (g) of the two chicory varieties as affected by the three harvest ages in $2014 / 2015$ and 2015/2016 seasons

\begin{tabular}{|c|c|c|c|c|c|c|c|c|}
\hline \multirow{2}{*}{$\begin{array}{l}\text { Characters } \\
\text { Treatments }\end{array}$} & \multicolumn{2}{|c|}{$\begin{array}{l}\text { Root length } \\
(\mathrm{cm})\end{array}$} & \multicolumn{2}{|c|}{ Root diameter (cm) } & \multicolumn{2}{|c|}{ Root fresh weight (g) } & \multicolumn{2}{|c|}{$\begin{array}{c}\text { Foliage fresh weigh } \\
\text { (g) }\end{array}$} \\
\hline & $2014 / 15$ & $2015 / 16$ & $2014 / 15$ & $2015 / 16$ & $2014 / 15$ & $2015 / 16$ & $2014 / 15$ & $2015 / 16$ \\
\hline$\overline{\text { Varieties (V) }}$ & & & & & & & & \\
\hline Nues & 23.1 & 23.8 & $5.6 \mathrm{~b}$ & $5.8 \mathrm{~b}$ & $254 \mathrm{~b}$ & $269 b$ & $134 b$ & $149 b$ \\
\hline Eurobees & 26.5 & 26.8 & $6.9 \mathrm{a}$ & $7.2 \mathrm{a}$ & $287 \mathrm{a}$ & $298 \mathrm{a}$ & $148 \mathrm{a}$ & $162 \mathrm{a}$ \\
\hline F. test & NS & NS & $* *$ & $* *$ & $* *$ & $* *$ & $*$ & $* *$ \\
\hline Harvest ages $(\mathrm{H})$ & & & & & & & & \\
\hline H1 (125 day) & $23.4 b$ & $23.4 \mathrm{c}$ & $5.8 \mathrm{c}$ & $6.0 \mathrm{c}$ & $252 \mathrm{c}$ & $265 b$ & $165 \mathrm{a}$ & $178 \mathrm{a}$ \\
\hline H2 (145 day) & $25.0 \mathrm{a}$ & $25.3 b$ & $6.4 \mathrm{~b}$ & $6.5 \mathrm{~b}$ & $271 b$ & $282 \mathrm{ab}$ & $136 b$ & $152 b$ \\
\hline H3 (165 day) & $26.1 \mathrm{a}$ & $27.3 \mathrm{a}$ & $6.7 \mathrm{a}$ & $7.0 \mathrm{a}$ & $289 a$ & $304 a$ & $122 \mathrm{c}$ & $137 \mathrm{c}$ \\
\hline LSD at $5 \%$ & 1.4 & 0.69 & 0.2 & 0.3 & 16 & 27 & 14 & 11 \\
\hline $\mathrm{V} \times \mathrm{H}$ & NS & NS & NS & NS & NS & NS & NS & NS \\
\hline
\end{tabular}

$*, * *$ and $\mathrm{NS}$ at $0.05,0.01$ level of significance and not significant

The interactions between varieties and harvest ages of the mentioned traits were not reached to $5 \%$ level of significance.

Data in Table 4 show that the evaluated the two chicory varieties were differed significantly in root traits in the two seasons. Eurobees variety surpassed Nues variety in all mentioned traits. These variations between the two tested chicory varieties in these traits may be related to the increments of root formation and root dry matter $\%$ which referred to their gene potential. These results are in line with those mentioned by Černý and Javor (2004) they mentioned that both of developmental and matter transformation processes are reflected into growth of chicory biomass. Therefore, the dependence of individual elements of chicory yield components on environmental conditions is very different.

Table 4. Root dry matter\%, root dry weight (g), and top fresh yield (t/fed) of the two chicory varieties as affected by the three harvest ages in $2014 / 2015$ and $2015 / 2016$ seasons

\begin{tabular}{|c|c|c|c|c|c|c|}
\hline \multirow{2}{*}{$\begin{array}{l}\text { Characters } \\
\text { Treatments }\end{array}$} & \multicolumn{2}{|c|}{ Root dry matter\% } & \multicolumn{2}{|c|}{ Root dry weight (g) } & \multicolumn{2}{|c|}{ Top fresh yield(t./fed) } \\
\hline & $2014 / 15$ & $2015 / 16$ & $2014 / 15$ & $2015 / 16$ & 2014/15 & $2015 / 16$ \\
\hline \multicolumn{7}{|l|}{ Varieties (V) } \\
\hline Nues & $25.38 \mathrm{~b}$ & $25.72 b$ & $64.65 b$ & $69.22 b$ & $5.44 b$ & $5.72 b$ \\
\hline Eurobees & $25.96 \mathrm{a}$ & $26.33 \mathrm{a}$ & $74.59 a$ & $78.59 a$ & $6.33 a$ & $6.72 \mathrm{a}$ \\
\hline F. test & $*$ & $*$ & $* *$ & $* *$ & $* *$ & $* *$ \\
\hline \multicolumn{7}{|l|}{ Harvest ages $(\mathrm{H})$} \\
\hline H1 (125 day) & $24.13 b$ & $24.67 \mathrm{c}$ & $60.89 \mathrm{c}$ & $65.29 c$ & $6.92 \mathrm{a}$ & $7.26 \mathrm{a}$ \\
\hline H2 (145 day) & $25.91 \mathrm{a}$ & $26.13 b$ & $70.12 b$ & $73.55 b$ & $5.86 \mathrm{~b}$ & $6.30 \mathrm{~b}$ \\
\hline H3 (165 day) & $26.98 \mathrm{a}$ & $27.27 \mathrm{a}$ & $77.86 a$ & $82.87 \mathrm{a}$ & $4.87 \mathrm{c}$ & $5.11 \mathrm{c}$ \\
\hline LSD at $5 \%$ & 1.10 & 0.80 & 3.99 & 6.97 & 0.59 & 0.53 \\
\hline $\mathrm{V} \times \mathrm{H}$ & NS & NS & NS & NS & NS & NS \\
\hline
\end{tabular}

*,** and NS at $0.05,0.01$ level of significance and not significant

Data in the same Table cleared that root dry matter\% and root dry weight $(\mathrm{g})$ significantly increased with delaying harvest age from 125 to 145 and up to 165 days after sowing in both seasons. Meanwhile, top fresh yield $(\mathrm{t} / \mathrm{fed})$ recorded the highest values when plants were harvested in the earlier harvesting age. These results proved that maturity stage was still continued to complete the storing processing of dry matter from leaves to roots. The distinct effect of delaying harvest dates on these traits is mainly due to the favorable climatic conditions especially the temperature degree in this stage which accelerated dry matter $\%$ as a mass production which resulted highest root dry weight. These results partially agreed with those reported by Monti et al. (2005), they stated that root dry matter\% and root dry weight accumulation were increased by long growing season and high temperature conditions especially in maturity stage.
All mentioned traits were insignificantly affected by the interaction between harvest age and varieties in both seasons.

Results in Table 5 manifest that Eurobees variety significantly surpassed Nues in all mentioned traits in both seasons. The superiority of Eurobees variety may be correlated to the increment in root dimensions, and root fresh weight which finally participated in getting higher values of roots fresh, dry, inulin yields/fed, and inulin $\%$ as well as root dry matter\% (Table 3) as compared to Nues variety. These results are in line with those mentioned by Baert (1997), Černý et al. (2008) and Papetti et al. (2013).

Data in the same Table cleared that delaying harvest age from 125 to 145 and up to 165 days after sowing caused significant increments in root fresh and dry yields as well as inulin \% and inulin yield amounted by 0.80 and 1.30 corresponding 1.03 and 1.61 tons in root fresh yield, as well 0.41 and 0.67 corresponding to 0.44 and 0.73 tons of root dry yield, and also 
amounted by 11.12 and $21.29 \%$ corresponding to 12.13 and $21.64 \%$ of inulin $\%$, moreover 0.64 and 1.19 corresponding to 0.71 and 1.28 tons of inulin yield ( $t /$ fed) as compared to the first harvest age (125 days) in the $1^{\text {st }}$ and $2^{\text {nd }}$ seasons, respectively. These results are in line with those obtained by Černý et al. (2008) they confirmed that the root fresh yield and inulin content were statistically high significantly influenced by year's weather conditions, meanwhile Wilson et al. (2004) concluded that the inulin accumulation in a root depends on environmental conditions especially high temperature and physiological state of plants.

Table 5. Root fresh yield, root dry yield, inulin yield and Inulin\% of the two chicory varieties as affected by the three harvest ages in $2014 / 2015$ and $2015 / 2016$ seasons

\begin{tabular}{|c|c|c|c|c|c|c|c|c|}
\hline \multirow{2}{*}{$\begin{array}{l}\text { Characters } \\
\text { Treatments }\end{array}$} & \multicolumn{4}{|c|}{ Root fresh yield (t/fed) Root dry yield (t/fed) } & \multicolumn{2}{|c|}{ Inulin\% } & \multicolumn{2}{|c|}{ Inulin yield (t/fed) } \\
\hline & 2014/15 & 2015/16 & $2014 / 15$ & 2015/16 & 2014/15 & 2015/16 & $2014 / 15$ & 2015/16 \\
\hline Varieties (V) & & & & & & & & \\
\hline Nues & $11.32 \mathrm{~b}$ & $11.59 b$ & $2.88 \mathrm{~b}$ & $2.99 \mathrm{~b}$ & $78.90 \mathrm{~b}$ & $79.64 b$ & $2.30 \mathrm{~b}$ & $2.41 \mathrm{~b}$ \\
\hline Eurobees & $12.60 \mathrm{a}$ & $12.74 \mathrm{a}$ & $3.28 \mathrm{a}$ & $3.31 \mathrm{a}$ & $83.15 \mathrm{a}$ & $84.85 \mathrm{a}$ & $2.75 \mathrm{a}$ & $2.84 \mathrm{a}$ \\
\hline F. test & $* *$ & $* *$ & ** & ** & $* *$ & * & ** & $* *$ \\
\hline Harvest ages $(\mathrm{H})$ & & & & & & & & \\
\hline H1 (125 day) & $11.26 \mathrm{c}$ & $11.28 \mathrm{c}$ & $2.72 \mathrm{c}$ & $2.76 \mathrm{c}$ & $70.22 \mathrm{c}$ & $70.99 c$ & $1.91 \mathrm{c}$ & $1.96 \mathrm{c}$ \\
\hline H2 (145 day) & $12.06 \mathrm{~b}$ & $12.31 \mathrm{~b}$ & $3.13 b$ & $3.20 \mathrm{~b}$ & $81.34 b$ & $83.12 b$ & $2.55 \mathrm{~b}$ & $2.67 \mathrm{~b}$ \\
\hline H3 (165 day) & $12.56 \mathrm{a}$ & $12.89 \mathrm{a}$ & $3.39 \mathrm{a}$ & $3.49 \mathrm{a}$ & $91.51 \mathrm{a}$ & $92.63 a$ & $3.10 \mathrm{a}$ & $3.24 \mathrm{a}$ \\
\hline LSD at $5 \%$ & 0.39 & 0.47 & 0.14 & 0.17 & 3.51 & 3.85 & 0.13 & 0.22 \\
\hline $\mathrm{V} \times \mathrm{H}$ & $*$ & $*$ & $*$ & $*$ & * & * & $*$ & * \\
\hline
\end{tabular}

*,** and NS at $0.05,0.01$ level of significance and insignificant

Data in Table 6 show that root fresh yield, root dry yield, inulin $\%$ and inulin yield $(\mathrm{t} / \mathrm{fed})$ were significantly affected by the interaction between varieties and harvest ages in both seasons. Eurobees variety achieved the highest significant values of fresh and dry root and inulin yields/fed when delayed harvest age from 165 days after sowing as compared to Nues variety which harvested at 125 days in both seasons. Both Eurobees and Nues varieties which harvested at 165 days from sowing attained the highest significant variance of inulin $\%$ as compared to its harvested of them at 125 and 145 days after sowing.

Table 6. Significant interactions effect between varieties and harvesting ages on yields of root fresh, root dry, inulin ( $t /$ fed) and inulin $\%$ in 2014/15 and 2015/16 seasons

\begin{tabular}{|c|c|c|c|c|c|c|c|c|c|}
\hline \multirow{2}{*}{\multicolumn{2}{|c|}{ Interaction effects }} & \multicolumn{2}{|c|}{$\begin{array}{l}\text { Root fresh yield } \\
\text { (t/fed) }\end{array}$} & \multicolumn{2}{|c|}{ Root dry yield (t/fed) } & \multicolumn{2}{|c|}{ Inulin\% } & \multicolumn{2}{|c|}{ Inulin yield $(t / f e d)$} \\
\hline & & $2014 / 15$ & $2015 / 16$ & $2014 / 15$ & 2015/16 & $2014 / 15$ & $2015 / 16$ & $2014 / 15$ & $2015 / 16$ \\
\hline \multicolumn{10}{|c|}{ Varieties $\mathrm{x}$ harvest ages $(\mathrm{V} \times \mathrm{H})$} \\
\hline & $\mathrm{H} 1$ & $10.68 \mathrm{~d}$ & $10.68 \mathrm{~d}$ & $2.54 \mathrm{~d}$ & $2.61 d$ & $67.52 \mathrm{e}$ & $67.69 \mathrm{e}$ & $1.72 \mathrm{~d}$ & $1.77 \mathrm{~d}$ \\
\hline \multirow{3}{*}{ Nues } & $\mathrm{H} 2$ & $11.29 \mathrm{c}$ & $11.76 \mathrm{c}$ & $2.90 \mathrm{c}$ & $3.03 \mathrm{c}$ & 78. & $79.98 \mathrm{c}$ & $2.28 \mathrm{c}$ & $2.43 \mathrm{c}$ \\
\hline & $\mathrm{H} 3$ & $11.99 \mathrm{~b}$ & $12.32 \mathrm{bc}$ & $3.20 \mathrm{~b}$ & $3.32 \mathrm{~b}$ & $90.45 \mathrm{a}$ & $91.25 \mathrm{ab}$ & $2.89 \mathrm{~b}$ & $3.03 \mathrm{~b}$ \\
\hline & H1 & $11.83 \mathrm{~b}$ & $11.89 \mathrm{c}$ & $2.89 \mathrm{c}$ & $2.90 \mathrm{c}$ & $72.93 d$ & $74.29 \mathrm{~d}$ & $2.11 \mathrm{c}$ & $2.16 \mathrm{c}$ \\
\hline \multirow[t]{2}{*}{ Eurobees } & $\mathrm{H} 2$ & $12.83 \mathrm{a}$ & $12.86 \mathrm{ab}$ & $3.35 b$ & $3.36 \mathrm{~b}$ & $83.97 \mathrm{~b}$ & $86.27 \mathrm{~b}$ & $2.82 \mathrm{~b}$ & $2.90 \mathrm{~b}$ \\
\hline & $\mathrm{H} 3$ & $13.12 \mathrm{a}$ & $13.46 \mathrm{a}$ & $3.58 \mathrm{a}$ & $3.67 \mathrm{a}$ & $92.57 \mathrm{a}$ & $94.63 \mathrm{a}$ & $3.32 \mathrm{a}$ & $3.45 \mathrm{a}$ \\
\hline
\end{tabular}

Means with the same letter in each column, on the basis of Duncan test, have no significant differences at $5 \%$ level.

H1: harvesting date after 125 days from sowing, H2: 145 days from sowing and H3: 165 days from sowing.

Data in Table 7 show that chemical analyses of crud extracted inulin from two root chicory varieties detected us varieties Eurobees and Nues were varied considerably in their performance in both seasons for root inuline \%, chain length distribution and sugar profile (glucose, fructose and total reducing sugar).

Moreover, total fructose $\%$ tended to increase and total glucose decreased with delaying harvest time for each variety whereas, increasing fructose levels from the first age up to latest harvest age associates with onset of cooler night at minimum temperatures which ranged from $\left(7.1\right.$ to $\left.12.6^{\circ} \mathrm{C}\right)$ as shown in table 2 in month of January, February and Marsh before harvest which suitable for accumulate sugar in the taproot. These results are in similar with those mentioned by Ernst et al. (1995) and Černý et al. (2008). A general pattern is a maximum chain length in latest harvest while decreased in the first and second harvest age. These findings are in agreement with those mentioned by Varallo et al. (1993) and Amaducci and Pritoni (1997).

Data in the same Table cleared that inulin chain length gradual increased with delaying harvest age from 125 to 145 and up to 165 day after sowing in both seasons

As for degree of polymerization (DP) as a class characteristic, the data obtained tells us Eurobees recorded the longest chine length because the DP $>10$ moreover associated with higher total reducing sugar\%, total fructose $\%$ and inulin $\%$ while Nues variety gave the shortest chine length with $\mathrm{DP}<10$ and associated with lowest total reducing sugar, total fructose $\%$ and inulin\%. These findings are in agreement with those mentioned by Meehye and Shin (1996), Wilson et al. (2004), Kovár and Cerný (2012) and Petkova et al. (2014) 
Table 7. Sugar profile, chain length (DP) and Inulin $\%$ of extracted inulin from both chicory roots varieties by enzymatic analysis at three harvest age in 2014/15 and 2015/16 seasons

\begin{tabular}{lcccccc}
\hline & \multicolumn{6}{c}{$\begin{array}{c}\text { Nues variety } \\
\text { Surobees } \\
\text { variety }\end{array}$} \\
& $\mathbf{H}_{\mathbf{1}}$ & $\mathbf{H}_{\mathbf{2}}$ & $\mathbf{H}_{\mathbf{3}}$ & $\mathbf{H}_{\mathbf{1}}$ & $\mathbf{H}_{\mathbf{2}}$ & $\mathbf{H}_{\mathbf{3}}$ \\
\hline Total reducing sugar\% & 36.5 & 41.0 & 45.70 & 59.70 & 69.9 & 74.9 \\
Total glucose\% & 5.7 & 5.5 & 5.2 & 4.2 & 4.4 & 4.3 \\
Total fructose\% & 30.8 & 35.5 & 40.5 & 55.5 & 65.5 & 70.6 \\
chain length (DP) & 6.4 & 7.4 & 8.7 & 14.2 & 15.8 & 17.4 \\
Inulin\% & 65.5078 .73 & 90.85 & 78.55 & 82.5391 .65 \\
\multicolumn{5}{c}{ harvest ages at 2015/2016 } \\
Total reducing sugar\% & 35.5 & 42.2 & 53.1 & 55.7 & 70.5 & 80.0 \\
Total glucose\% & 5.5 & 6.0 & 5.9 & 4.5 & 5.1 & 4.8 \\
Total fructose\% & 30.0 & 36.2 & 47.2 & 51.2 & 65.4 & 75.2 \\
chain length (DP) & 6.4 & 7.0 & 9 & 11.4 & 13.8 & 16.6 \\
Inulin\% & 67.9079 .88 & 79.24 & 75.99 & 83.1292 .20 \\
\hline
\end{tabular}

H1: harvesting date after 125 days from sowing, H2: 145 days from sowing and H3: 165 days from sowing.

Data presented in Table 8 show the chemical analysis of two tested root chicory varieties under this study. It was obviously clear that both chicory varieties had a high content of total carbohydrates and low level of protein, fat, ash and crude fiber. These findings are in agreement with those mentioned by Meehye and Shin (1996). Moreover, there are differences between them in the minerals content whereas, Nues variety was higher than other one in $\mathrm{Zn}, \mathrm{Fe}$, and $\mathrm{Ca}$ and $\mathrm{K} \mathrm{mg} / 100 \mathrm{~g}$. these results manifest that chicory is a great source of carbohydrates and minerals. The variations between two tested chicory varieties in these contents may be related to varietal characteristic and their performance which depends on many factors such as their gene make-up and environmental conditions. These results are in line with those mentioned by Dersch et al. (1993) and Černý et al. (2008).

Table 8. Chemical analysis of Eurobees and Nues chicory root variety on dry weight basis at 165 days from sowing

\begin{tabular}{lcc}
\hline \multirow{2}{*}{ Constituents (\%) } & \multicolumn{2}{c}{ chicory varieties } \\
& Eurobees variety & Nues variety \\
\hline Moisture & 5.9 & 6.7 \\
Crude Protein & 2.5 & 3.2 \\
Crude ether extract & 0.95 & 1.5 \\
Ash & 2.8 & 4.5 \\
Total carbohydrate & 87.85 & 84.1 \\
Crude fiber & 6.7 & 5.5 \\
Minerals (mg/100g) & & \\
Zinc (Zn) & 0.27 & 0.36 \\
Iron (Fe) & 0.76 & 0.98 \\
Calcium (Ca) & 28.92 & 37.5 \\
Potassium (K) & 30.74 & 35.59 \\
\hline
\end{tabular}

\section{CONCLUSION}

Under conditions of this present work, it was found that both root chicory varieties which harvested at 165 days after sowing can be recommended to get the highest yields of fresh and dry roots/fed as well as inulin $\%$ and inulin yield/fed. Eurobees has the long chain length, while Nues variety has the short chain length which giving us the advantage of using them on a large scale in the food and pharmaceutical industries.

\section{REFERENCES}

Amaducci, S. and G. Pritoni (1997). Effect of harvest date and cultivar on Cichorium intybus L. yield components in north Italy, Indust. Crops and Products 7: 345-349.

Amin, A.A.W. (1997). Chemical and technological studies on treacle (Black Honey) Ph.D. Thesis presented to the Graduate School, Faculty of Agric., Alex. Univ., Egypt.

Andrea, M.; M.T. Amaducci; G. Pritoni and G. Venturi (2005). Growth, fructan yield, and quality of chicory (Cichorium intybus L.) as related to photosynthetic capacity, harvest time and water regime. J. Experimental Botany, 56(415):1389-1395.

AOAC (2010). Official Methods of Analysis of Association of Official Analytical Chemists. 18th Ed.,Washington, D.C., USA.

Baert, J.R.A. (1997). "The effect of sowing and harvest date and cultivar on inulin yield and composition of chicory (Cichorium intybus L.) roots." Indust. Crops and Products, 6 (3-4):195-199.

Baert, J.R.A. and E.J. Van Bockstaele (1993). Cultivation and breeding of root chicory for inulin production. Indust. Crops Prod., 1:229-234.

Černý, I. and D. Javor (2004). Variety - an important intensification factor of Chicory (Cichorium intybus L.) growing. Naše pole 5: 22-25.

Černý, I.; V. Pačuta and M. Kovár (2008). Yield and quality of chicory (Cichorium intybus L.) in dependence on variety and foliar application of atonik and polybor 150 composition is influenced by cultivar selection, planting and harvest date. Crop Sci., 44:748-752.

Dersch, G.; S. Kammerer and W. Praznik (1993). Harvest dates and varietal effects on yield, concentration and composition of carbohydrates in chicory roots. In: Proceedings of the 2nd European Symposium on Industrial Crops and Products, Pisa.

Duncan, D.B. (1955). Multiple ranges and multiple F. test. Biomtrice, 11:1-42.

Ernst, M.; N.J. Chatterton and P.A. Harrison (1995). Carbohydrate changes in chicory (Cichorium intybus L. var. foliosum) during growth and storage. Scientia Horticulturae 63:251-261

F.A.O. (2013). FAOSTAT. Retrieved from faostat.fao.org.

González, H.S.M.; R.R. Herrera; M.G. López; O.M. Rutiaga; C.N. Aguilar and J.C. Esquivel (2015). Inulin in food products: Prebiotic and functionalingredient. British Food J., 117:371-387.

Kovar,, M. and I. Černý (2012). Regulation of production performance of chicory plants by foliar application of biologically active substances. J. Central Euro. Agric., 13(4):747-759.

Kristine, K.; R. Andersson; I. Rydberg and A. Perman (1999). Influence of harvest date on inulin chain length distribution and sugar profile for six chicory (Cichorium intybus L). J. Sci., Food Agric., 79:1503-1506.

Leite, J.T.C., P. Martinelli , F.E.X. Murr and K.J. Park (2004). Study of the inulin concentration by physical methods. Proceedings of the $14^{\text {th }}$ International Drying Symposium, São Paulo, Brazil,22-25 August, vol. B, pp. 868-875. 
Meehye, K. and H.K. Shin (1996). The water-soluble extract of chicory reduces glucose uptake from the perfused jejunum in rats. J. Nut., 126(9): 2236-2242.

Monti, A., Amaducci, M.T., Pritoni, G., Venturi, G., (2005). Growth, fructan yield, and quality of chicory (Cichorium intybus L.) as related to photosynthetic capacity,harvest time, and water regime. Journal of Experimental Botany 56 (415):1389-1395.

Papetti, A.; D. Mascherpaa and C. Carazzonea (2013). Identification of organic acids in Cichorium intybus inhibiting virulence-related properties of oral pathogenic bacteria. Food Chemistry 138(23):1706-1712.

Petkova, N.; M. Ognyanov and P. Denev (2014). Isolation and charaterization of inulin obtained from taproots of common chicory (Cichorium intybus L.). Univ., of Plovdiv "Paisii Hilendarski"-Bulgaria, Scientific Papers - Chemistry, 39, Book 5.

Petkova, N.; M. Ognyanov; M. Todorova and P. Denev (2015). Ultrasound-assisted extraction and characterisation of inulin-type fructan from roots of elecampane (Inula helenium L.), ASN, 225-235

Piper, C.S. (1955). Soil and plant analysis. Univ. of Adelaide, Australia, P.178.

Ritsema, T. and S.C. Smeekens (2003). Engineering fructan metabolism in plants. J. Plant Physiol.,160: 811-820.

Sayed, Hala S. and Soha, R. Khalil (2017). Effect of chicory inulin extract as a fat replacer on texture and sensory properties of cookies. Middle East J. Appl. Sci., 7(1): 168-177

Schittenhelm, S. (1999). Agronomic performance of root chicory, Jerusalem artichoke, and sugar beet in stress and non-stress environments. Crop Sci., 39:18151823.

Schittenhelm, S. (2001). Effect of sowing date on the performance of root chicory. Europ. J. Agron., 15: 209-220.

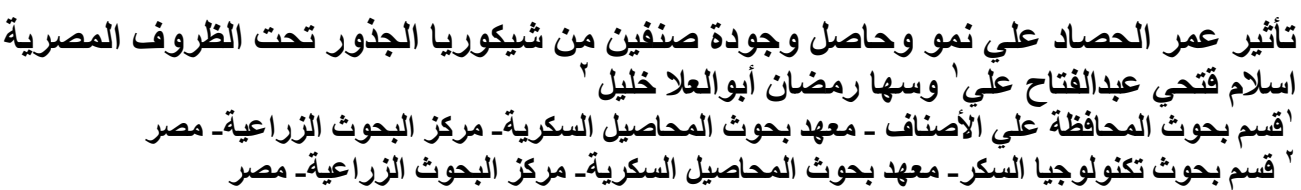

الثيكوريا محصول شتوي ينتمي الي العائلة المركبة، حيث يخزن الإنيولين في الجذور ـ تعتبر الشيكوريا محصول نقدي ، حيث أن الأنيولين

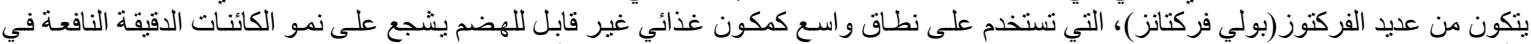

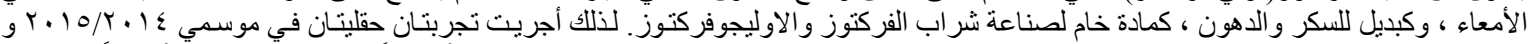

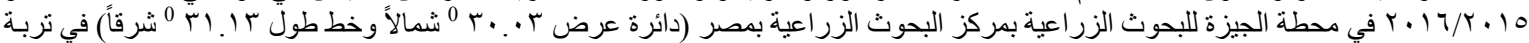

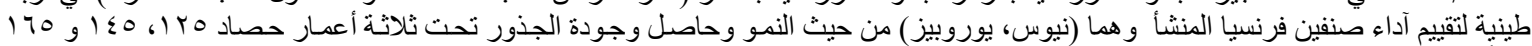

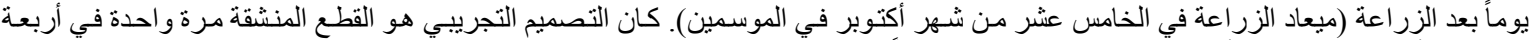

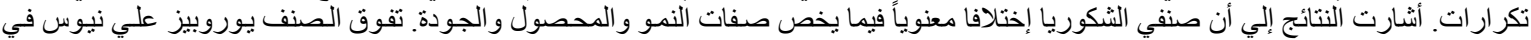

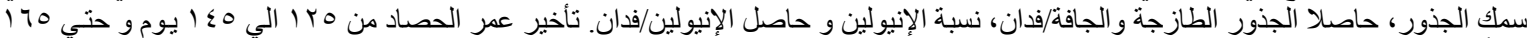

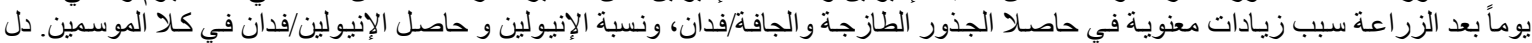

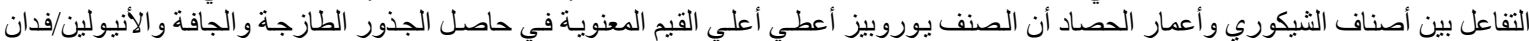

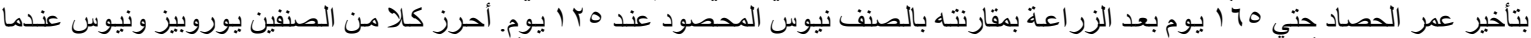

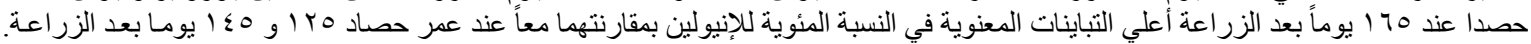

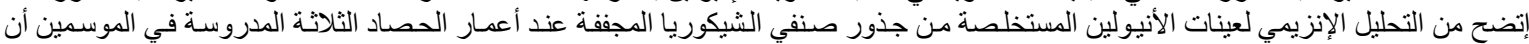

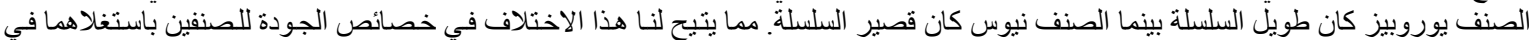

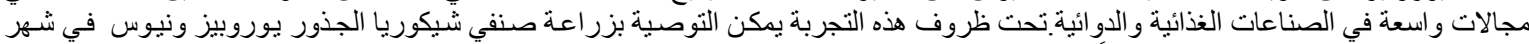

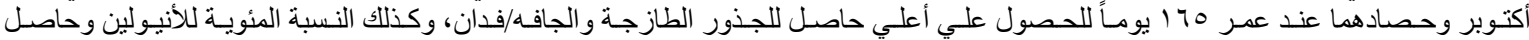
الأنيولين/فدان. 